\title{
ANTIBACTERIAL EFFICIENCY OF MODAL FABRIC TREATED WITH OXIDES OF Ti/Si/Zn NANOCOMPOSITES
}

\author{
A. R. Arul ${ }^{1}$, T. E. Manjulavalli ${ }^{2}$, R. Venckatesh ${ }^{3}$ and G. Rajkumar ${ }^{4}$ \\ ${ }^{1}$ Department of Physics, Kumaraguru College of Technology,Coimbatore-641 049, India \\ ${ }^{2}$ Department of Physics, NGM College, Pollachi- 642001, India \\ ${ }^{3}$ Department of Chemistry, Government Arts College, Udumalpet-642126, India \\ ${ }^{4}$ Department of Fashion Technology, Kumaraguru College of Technology, \\ Coimbatore-641 049, India \\ *E-mail : emanjhu@gmail.com
}

\begin{abstract}
The antibacterial efficiency of nano $\mathrm{TiO}_{2}, \mathrm{TiO}_{2} / \mathrm{SiO}_{2}, \mathrm{TiO}_{2} / \mathrm{ZnO}$ and $\mathrm{TiO}_{2} / \mathrm{SiO}_{2} / \mathrm{ZnO}$ Nanocomposites coated on modal fabric using dip coating was evaluated using Fourier infrared spectroscopy, Transmission electron microscopy, scanning electron microscopy and zone of inhibition against Bacillus subttilis. The particle size varies between 17.9 $\mathrm{nm}$ to $46.4 \mathrm{~nm}$. The fabric treated with $\mathrm{TiO}_{2} / \mathrm{SiO}_{2} / \mathrm{ZnO}$ exhibited a maximum zone of inhibition of $53 \mathrm{~mm}$ followed by $47 \mathrm{~mm}$ and $43 \mathrm{~mm}$ for $\mathrm{TiO}_{2}$ and $\mathrm{TiO}_{2} / \mathrm{ZnO}$ treated fabrics respectively. $\mathrm{TiO}_{2} / \mathrm{SiO}_{2}$ treated fabric has shown a minimal zone of inhibition of $36 \mathrm{~mm}$.
\end{abstract}

Keywords: Antibacterial efficiency, Nanocomposite, SEM, Modal fabric, FTIR

@ RASĀYAN. All rights reserved

\section{INTRODUCTION}

Controlling for harmful effects created by microorganisms is an important task in the present scenario for the healthier living of human beings. Natural equilibrium with the human body and living environments has a broad range of microorganisms, but a rapid and uncontrolled fast thriving of microbes can lead to some serious problems. ${ }^{1-3}$

Clothing is one of the basic needs of human beings and different kinds of textile fibers are used for human clothing where comfort is the prime factor. Textiles provide a suitable substrate to grow microorganisms, especially at appropriate humidity and temperature, in contact with human body. The microorganisms have made three undesirable effects on textiles. The first includes degradation phenomena like coloring, staining, and determination of fibers and the second, producing an unpleasant odor, and finally, the third effect is an increase of potential health risks. ${ }^{4-6}$ Hence, it becomes essential that the textile materials should have some form of antibacterial protection imbibed in them if they are designed to use for longer period of time. Application of inorganic nanoparticles and their nanocomposites on textile materials have given a wide opportunity for antimicrobial and multifunctional modification of textiles. ${ }^{7}$ In most of the research materials, $\mathrm{TiO}_{2}, \mathrm{SiO}_{2}$, and $\mathrm{ZnO}$ nanoparticles have been used to achieve antibacterial properties in textiles. An enhancement in the antibacterial property was found in the modified nano $\mathrm{TiO}_{2}$ treated cotton fabrics. ${ }^{8}$ In the antimicrobial treatment of cotton fabrics by $\mathrm{TiO}_{2}$ nanoparticles; smaller nanoparticles have shown better results. ${ }^{9}$ Nano $\mathrm{SiO}_{2}$ treated textiles have provided better microbiological controls in hospital interiors. ${ }^{10} \mathrm{~A}$ significant result was observed in the zinc oxide nanoparticle treated cotton fabrics against S.Aureus. ${ }^{11}$ In the $\mathrm{ZnO} / \mathrm{TiO}_{2}$ composite treated nylon/cotton blended fabric, the highest antibacterial property against E.coli and S.Aureuswas obtained at a concentration of $60 \mathrm{ppm}^{12}$

Many researchers have worked on the antibacterial modification of textiles on natural fibers such as cotton and wool, cotton/polyester, nylon/cotton. ${ }^{13-17}$ No literature is found on the antibacterial finishing of modal fabric. Modal is a regenerated cellulosic fiber and second generation viscose fiber. It is made out of pure wooden chips from the beech tree. High wet strength and extra softness are the distinguishing properties of 
modal. It has excellent drape, good hygroscopic properties, good moisture regain and air permeability. Modal has $50 \%$ more hygroscopic per unit volume than cotton. ${ }^{18}$ Therefore, it is considered best for exercising clothing and health suit. Hence, this research work aims at the application and characterization of nano $\mathrm{TiO}_{2}, \mathrm{TiO}_{2} / \mathrm{SiO}_{2}, \mathrm{TiO}_{2} / \mathrm{ZnO}$ and $\mathrm{TiO}_{2} / \mathrm{SiO}_{2} / \mathrm{ZnO}$ nanocomposites coated on modal fabric using dip coating technique for the antibacterial efficacy.

\section{EXPERIMENTAL}

\section{Materials and reagents}

The bleached single jersey modal fabric was fabricated and the geometrical parameters of the fabric are given in Table-1. The chemicals used for the synthesis of $\mathrm{TiO}_{2}, \mathrm{TiO}_{2} / \mathrm{SiO}_{2}, \mathrm{TiO}_{2} / \mathrm{ZnO}$ and $\mathrm{TiO}_{2} / \mathrm{SiO}_{2} / \mathrm{ZnO}$ are TTIP (Titanium tetra isopropoxide), hydrochloric acid, ethanol, silicic acid, THF (Tetrahydrofuran) and $\mathrm{ZnCl}_{2}$ which were procured from S.d.Fine chemicals, India. Lissapaln and acrylic binder were sourced from $\mathrm{M} / \mathrm{s}$ Jeeva Chemicals, Tirupur, India. Bacillus subttillis (Gram-positive) bacteria was used to ascertain the antibacterial activity of nanoparticles coated modal fabric which was obtained from IMTEK, Chandigarh, India.

Table-1: Geometrical parameters of modal fabric

\begin{tabular}{c|c|c|c|c|c|c|c|c}
\hline \multirow{2}{*}{ Material } & \multicolumn{9}{|c|}{ Geometrical Parameters } \\
\cline { 2 - 8 } & $\begin{array}{c}\text { Yarn } \\
\text { Count (Ne) }\end{array}$ & $\begin{array}{c}\text { Course } \\
\text { /inch }\end{array}$ & $\begin{array}{c}\text { Wales } \\
\text { /inch }\end{array}$ & $\begin{array}{c}\text { Stitch } \\
\text { Density }\end{array}$ & $\begin{array}{c}\text { Areal Density } \\
\left(\mathrm{g} / \mathrm{m}^{2}\right)\end{array}$ & $\begin{array}{c}\text { Thickness } \\
(\mathrm{mm})\end{array}$ & $\begin{array}{c}\text { Loop } \\
\text { length } \\
(\mathrm{cm})\end{array}$ & $\begin{array}{c}\text { Tightness } \\
\text { factor }\end{array}$ \\
\hline $\begin{array}{c}\text { Modal } \\
\text { Fabric }\end{array}$ & 26 & 34 & 23 & 782 & 184 & 0.49 & 0.46 & 10.23 \\
\hline
\end{tabular}

\section{Synthesis of $\mathrm{TiO}_{2}$ nanoparticles}

Sol-gel (Wet chemical) technique was adopted for the synthesis of $\mathrm{TiO}_{2}$ nano particles. TTIP (Titanium tetra isopropoxide), hydrochloric acid and ethanol were used as a precursor, peptizing agent, and solvent medium respectively. TTIP was added to the ratio of 1:4:2 to a mixture containing hydrochloric acid and ethanol. The mixture was stirred for 1 hour at room temperature. Then $50 \mathrm{ml}$ of distilled water was added to it and the temperature was raised to $50^{\circ} \mathrm{C}$ and stirred for 3 hours until the solution changed into a colorless gel. The high viscous gel was dried at room temperature to obtain a fine powder. The resulting powder was heated at $110^{\circ} \mathrm{C}$ for 1 hour in a hot air oven. Finally, the colorless powder was calcined at $600^{\circ} \mathrm{C} .^{19}$

\section{Synthesis of $\mathrm{TiO}_{2} / \mathrm{SiO}_{2}$ nanocomposite}

$\mathrm{SiO}_{2}$ solution was prepared by mixing silicic acid with THF (Tetrahydrofuran) in the ratio of 1:2. $\mathrm{SiO}_{2}$ sol was added drop-by-drop to the $\mathrm{TiO}_{2}$ sol, which resulted in a yellowish brown solution. The mixture was stirred for 3 hours at room temperature, then the temperature was raised to $80^{\circ} \mathrm{C}$, and stirring was continued for an hour. Finally, yellowish brown color changed to yellow, and then the solution was dried at room temperature. The final product was heated in hot air oven for about $110^{\circ} \mathrm{C}$ for 1 hour. Finally, all the composites were calcined at $600^{\circ}$ C. ${ }^{19}$

\section{Synthesis of $\mathrm{TiO}_{2} / \mathrm{ZnO}$ nanocomposite}

$\mathrm{ZnO}$ sol was prepared by dissolving $\mathrm{ZnCl}_{2}$ in double distilled water. The mixture was stirred for 1 hour at $100^{\circ} \mathrm{C}$. $\mathrm{ZnO}$ was added drop-by-drop to the $\mathrm{TiO}_{2}$ sol, then the temperature was raised to $100^{\circ} \mathrm{C}$, and stirring was continued for an hour. Finally, a colorless gel changed to grey, and then the solution was dried at room temperature. The powder thus obtained was heated in a hot air oven at about $110^{\circ} \mathrm{C}$ for 1 hour. Finally, all the composites were calcined at $600^{\circ} \mathrm{C}$.

\section{Synthesis of $\mathrm{TiO}_{2} / \mathrm{SiO}_{2} / \mathrm{ZnO}$ nanocomposite}

$\mathrm{ZnO}$ sol was prepared using $\mathrm{ZnCl}_{2}$ which was dissolved in double distilled water. The mixture was stirred for 1 hour and maintained at $110^{\circ} \mathrm{C}$. $\mathrm{ZnO}$ was added drop-by-drop to the $\mathrm{TiO}_{2}-\mathrm{SiO}_{2}$ sol, then the temperature was raised to $120^{\circ} \mathrm{C}$, and stirring was continued for an hour. Finally, the yellow color changed 
to light grey, and then the solution was dried at room temperature. Grey powder was then heated in hot air oven for about $110^{\circ} \mathrm{C}$ for 1 hour. Finally, all the composites were calcined at $600^{\circ} \mathrm{C}$.

\section{Antibacterial finishing of fabrics}

$0.2 \mathrm{~g}$ of nanomaterial was taken in a beaker with $10 \mathrm{ml}$ distilled water. $0.5 \mathrm{ml}$ of acrylic binder and $1 \mathrm{ml}$ of surfactant were added to the same beaker. This solution was prepared at $30^{\circ} \mathrm{C}$. Then the solution was sonicated for $15 \mathrm{~min}$ at a frequency of $50 \mathrm{~Hz}$. Sonicated solution was immediately taken for coating in antibacterial finishing bath. The sample was treated by dip coating method. The modal fabric of size 3X3 $\mathrm{cm}$ was dipped in the solution for $10 \mathrm{~min}$ and padded using automatic paddler. The fabric was dried at $110^{\circ}$ $\mathrm{C}$ for 4 minutes and cured at $150^{\circ} \mathrm{C}$ for 3 minutes in an oven. The same procedure was followed for all the four samples.

\section{Surface Morphology Studies}

The surface morphology of fabric samples treated with nanoparticles was examined by Carl Zeiss (Sigma), UK scanning electron microscope (SEM) with an accelerating voltage of $10 \mathrm{kV}$ at x 2500 magnification and transmission electron microscope (TEM) with energy dispersive X-ray spectrometer (EDS) (JEOL JEM 2100).

\section{Fourier infrared spectroscopy (FTIR)}

Fourier transform infrared spectroscopy (Bruker, USA) was used to characterize the structures of $\mathrm{TiO}_{2}$, $\mathrm{TiO}_{2} / \mathrm{SiO}_{2}, \mathrm{TiO}_{2} / \mathrm{ZnO}$ and $\mathrm{TiO}_{2} / \mathrm{SiO}_{2} / \mathrm{ZnO}$ coated modal fabrics with a resolution of $4 \mathrm{~cm}^{-1}$ in the range of $4000-400 \mathrm{~cm}^{-1}$.

\section{Antibacterial testing \\ The American Association of Textile Chemists and Colorists (AATCC) Test Method 147is a qualitative antimicrobial test used to detect bacteriostatic activity on textile materials. This antimicrobial fabric and textile testing method are useful for obtaining a rough estimate of activity by the size of the zone of inhibition and the narrowing of the streaks caused by the presence of the antimicrobial agent permitting an estimate of the residual antimicrobial activity.}

\section{Determination of Zone of Inhibition (ZOI)}

The required quantity of microbiological growth medium (Mueller Hinton Agar) was prepared and autoclaved at $120^{\circ} \mathrm{C}$ for 20 minutes. Approximately 10 to $20 \mathrm{ml}$ of the media was poured into sterile Petri plate. It was allowed for solidification. Midlog phase culture of Bacillus subttillis was spread on MHA plates. Fabric sample of size $2 \mathrm{~cm}^{2}$ was placed on the culture of Petri plate containing a pathogen. This was incubated for 24 to 48 hours at $37^{\circ} \mathrm{C}$. The sample was taken and zone of inhibition was measured on all four sides using a scale and the mean values were recorded and compared with the untreated control specimen.

\section{Transmission Electron Micrography(TEM)}

\section{RESULTS AND DISCUSSION}

The Transmission electron micrographic images of the $\mathrm{TiO}_{2}, \mathrm{TiO}_{2} / \mathrm{SiO}_{2}, \mathrm{TiO}_{2} / \mathrm{ZnO}$ and $\mathrm{TiO}_{2} / \mathrm{SiO}_{2} / \mathrm{ZnO}$ nanoparticles are shown in Fig.-1. It is observed that most of the particle appears to be the spherical shape and rod-like morphology having a size between $17.9 \mathrm{~nm}$ to $46.4 \mathrm{~nm}$. From TEM it is confirmed that the prepared particles are in nano range.

\section{FTIR Spectra}

The FTIR spectra of untreated fabric, $\mathrm{TiO}_{2}$ treated, $\mathrm{TiO}_{2} / \mathrm{SiO}_{2}$ treated, $\mathrm{TiO}_{2} / \mathrm{ZnO}$ treated and $\mathrm{TiO}_{2} / \mathrm{SiO}_{2}$ I $\mathrm{ZnO}$ treated fabrics are depicted in Fig.-2. The absorption band at $1425 \mathrm{~cm}^{-1}$ in Fig.-2(a) for the untreated fabric indicates the presence of both cellulose II and the amorphous cellulose which is the characteristic peak of the modal fiber. ${ }^{20}$ The band at $1336 \mathrm{~cm}^{-1}$ and $1312 \mathrm{~cm}^{-1}$ are assigned to both crystalline celluloses 
RASĀYAN J. Chem.

Vol. 10 | No. 4 |1455-1461 | October - December | 2017

(Cel I and Cel II). Furthermore, another important characteristic that peak value $893 \mathrm{~cm}^{-1}$ confirm the absence of cellulose I in the modal fiber. ${ }^{21}$

In Figure-2(b), a strong band in the range of $900 \mathrm{~cm}^{-1}$ and $500 \mathrm{~cm}^{-1}$ was observed which is associated with the characteristic vibrational modes of $\mathrm{TiO}_{2}$. This confirms the formation of the $\mathrm{TiO}_{2}$ mode in the modal fabric. ${ }^{9}$ A broad absorption peak at around $3332 \mathrm{~cm}^{-1}$ and $1643 \mathrm{~cm}^{-1}$ of molecular water was observed in the $\mathrm{TiO}_{2}$ treated modal fabric. ${ }^{8}$

The peaks around $1100 \mathrm{~cm}^{-1}$ and $800 \mathrm{~cm}^{-1}$ correspond to symmetric and asymmetric stretching vibrations of Si-O-Si bonds respectively in Fig.- 2(c). The peak at $450 \mathrm{~cm}^{-1}$ indicates the bending mode of Si-O-Si. A small peak at $1017 \mathrm{~cm}^{-1}$ confirms the bonding between Ti and Si. ${ }^{22} \mathrm{~A}$ broad peak at $3347 \mathrm{~cm}^{-1}$ indicates $\mathrm{OH}$ stretching due to the presence of hydroxyl groups in the fiber.
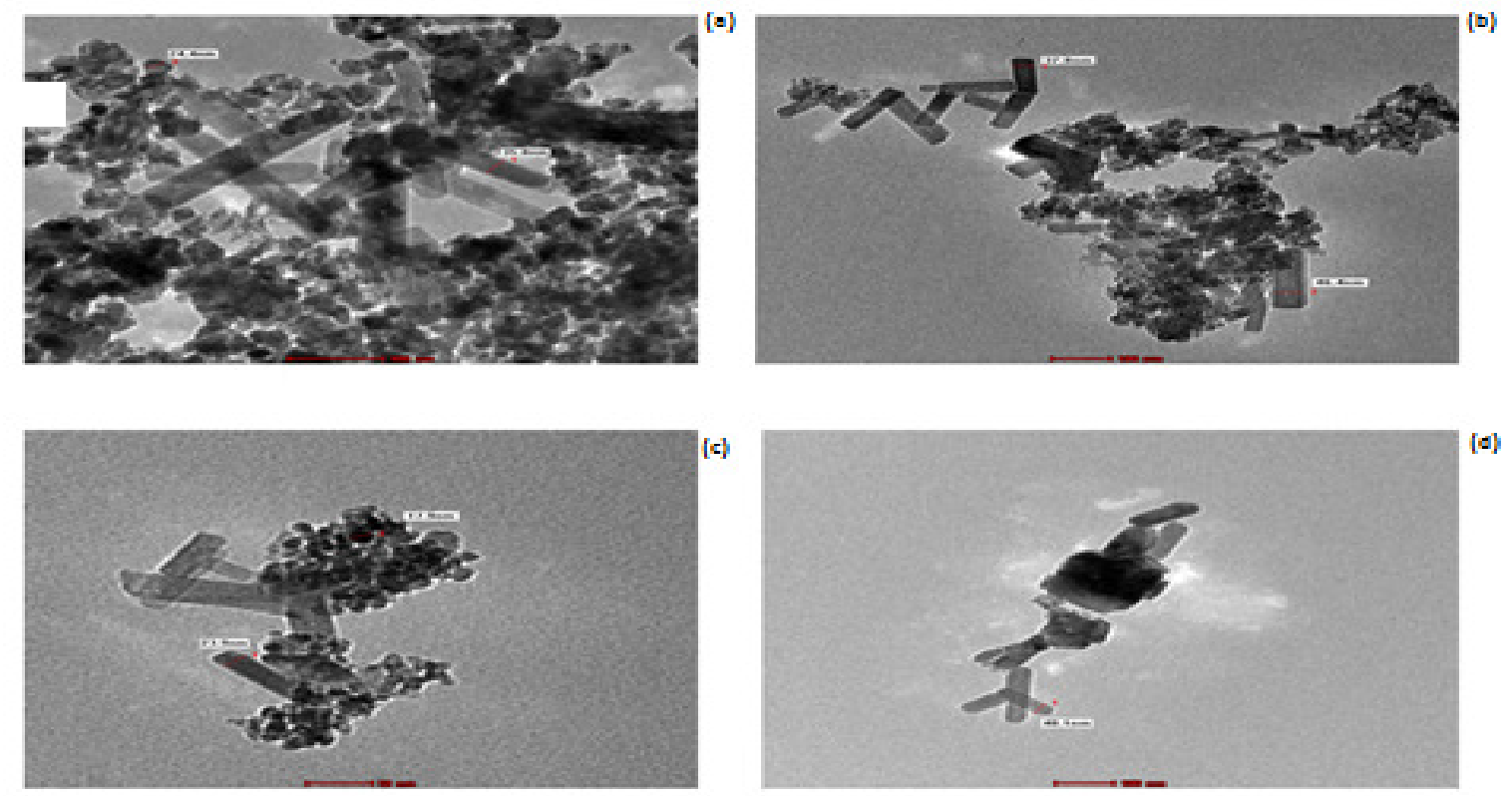

Fig.-1: Transmission electron microscopic images of the Nano composites (a) $\mathrm{TiO}_{2}$ (b) $\mathrm{TiO}_{2} / \mathrm{SiO}_{2}$ (c) $\mathrm{TiO}_{2} / \mathrm{ZnO}$ (d) $\mathrm{TiO}_{2} / \mathrm{SiO}_{2} / \mathrm{ZnO}$

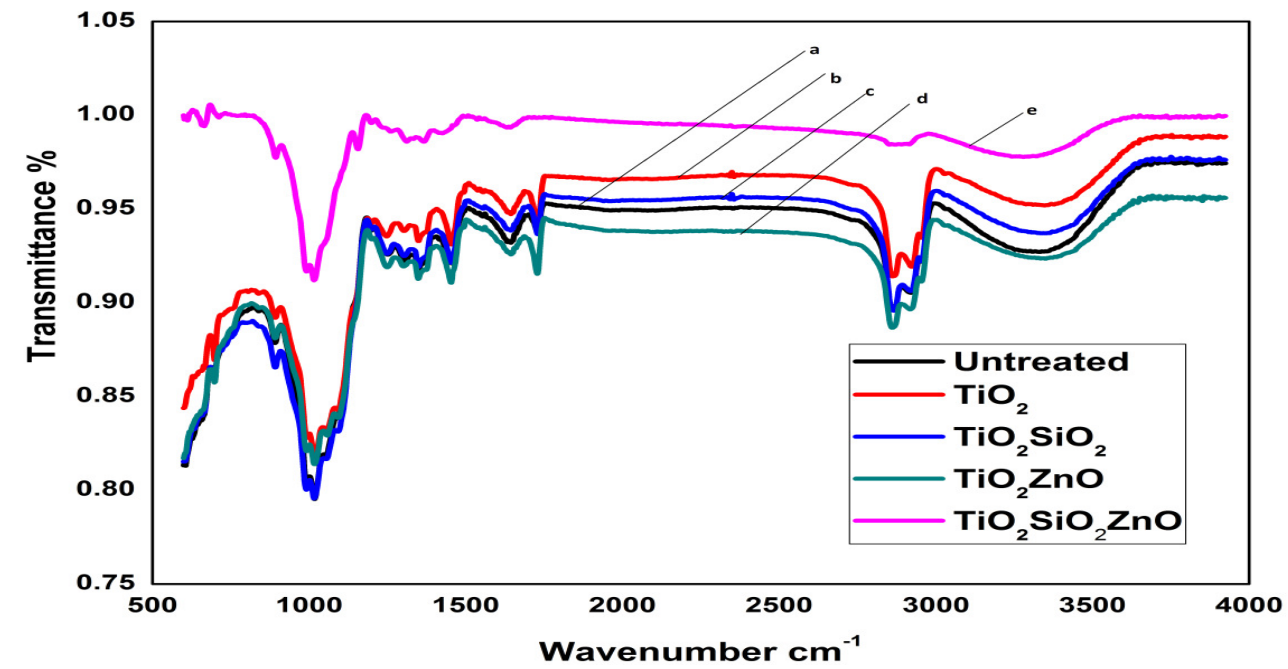

Fig.-2: Fourier transform infrared (FTIR) spectra of modal fabric(a) untreated fabric (b) Treated with $\mathrm{TiO}_{2}$ (c) treated with $\mathrm{TiO}_{2} / \mathrm{SiO}_{2}$ (d) treated with $\mathrm{TiO}_{2} / \mathrm{ZnO}$ (e) treated with $\mathrm{TiO}_{2} / \mathrm{SiO}_{2} / \mathrm{ZnO}$ nanocomposites 
RASĀYAN J. Chem.

Vol. 10 | No. 4 |1455-1461 | October - December | 2017

In Figure-2(d), the peak in the range $891 \mathrm{~cm}^{-1}$ and $500 \mathrm{~cm}^{-1}$ is associated with the characteristic vibrational modes of $\mathrm{TiO}_{2}$. The peak at $450 \mathrm{~cm}^{-1}$ indicates the $\mathrm{ZnO}$ absorption band. ${ }^{23}$ From this it is evident that both the $\mathrm{TiO}_{2}$ and $\mathrm{ZnO}$ modes are present in the modal fabric.

In Figure 2(e), the characteristic peaks of all the three nanoparticles such as $\mathrm{TiO}_{2}\left(891 \mathrm{~cm}^{-1}\right.$ and $500 \mathrm{~cm}^{-1}$, $\mathrm{SiO}_{2}\left(982 \mathrm{~cm}^{-1}\right)$ and $\mathrm{ZnO}\left(432 \mathrm{~cm}^{-1}\right)$ are obtained in the spectrum. ${ }^{24}$ This confirms the presence of all the three nanoparticles in the fabric.

\section{Antibacterial efficacy}

The results of disc diffusion tests in Fig.-3 shows the zone of inhibition of $\mathrm{TiO}_{2}, \mathrm{TiO}_{2} / \mathrm{SiO}_{2}, \mathrm{TiO}_{2} / \mathrm{ZnO}$ and $\mathrm{TiO}_{2} / \mathrm{SiO}_{2} / \mathrm{ZnO}$ treated modal fabrics for Bacillus subttilis. The growth of Bacillus subttilis around the untreated fabric is evident from the Fig.-3(a). The fabrics treated with nanoparticles have shown a reduction in the growth of the bacteria Bacillus subttilisaround the fabric surface which is clearly observed in Fig.3(b) to 3(e).
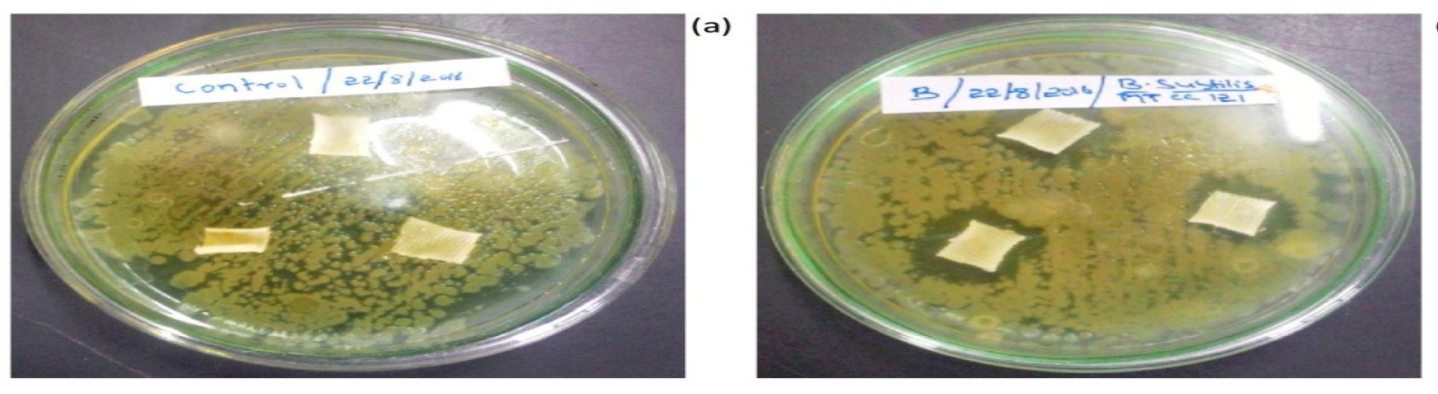

(b)
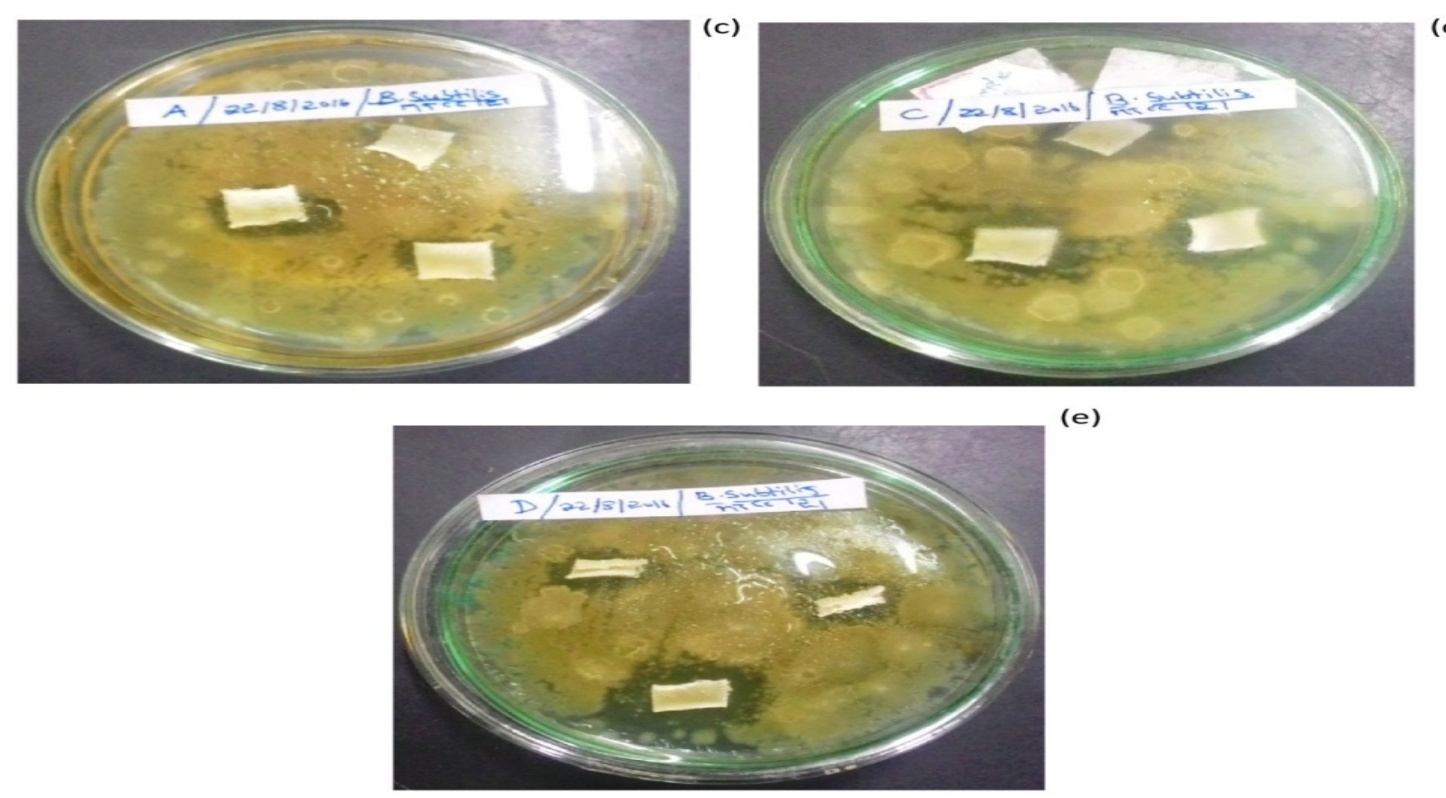

(e)

Fig.-3: Photographic images of Zone of inhibition of (a) untreated fabric (b) Treated with $\mathrm{TiO}_{2}$ (c) treated with $\mathrm{TiO}_{2}$ $/ \mathrm{SiO}_{2}(\mathrm{~d})$ treated With $\mathrm{TiO}_{2} / \mathrm{ZnO}(\mathrm{e})$ treated with $\mathrm{TiO}_{2} / \mathrm{SiO}_{2} / \mathrm{ZnO}$ nanocomposite

The fabric treated with $\mathrm{TiO}_{2} / \mathrm{SiO}_{2} / \mathrm{ZnO}$ has provided a maximum zone of inhibition of $53 \mathrm{~mm}$ in Fig.-4 followed by $\mathrm{TiO}_{2}$ treated sample $(47 \mathrm{~mm})$. This is due to the combined effect of $\mathrm{TiO}_{2} / \mathrm{SiO}_{2} / \mathrm{ZnO}$ nanoparticles present in a single component. The sample treated with $\mathrm{TiO}_{2} / \mathrm{ZnO}$ nanocomposite and $\mathrm{TiO}_{2}$ $/ \mathrm{SiO}_{2}$ nanocomposite have given a lower zone of inhibition of $43 \mathrm{~mm}$ and $36 \mathrm{~mm}$ respectively. The SEM micrographs of untreated, $\mathrm{TiO}_{2}$ treated, $\mathrm{TiO}_{2} / \mathrm{SiO}_{2}$ treated, $\mathrm{TiO}_{2} / \mathrm{ZnO}$ treated and $\mathrm{TiO}_{2} / \mathrm{SiO}_{2} / \mathrm{ZnO}$ treated 
RASĀYAN $J$. Chem.

Vol. 10 | No. 4 |1455-1461 | October - December | 2017

- modal fabric are depicted in Fig.-5(a) to 5(e). The nano particles were not found in untreated modal fabric in Fig.-5(a).

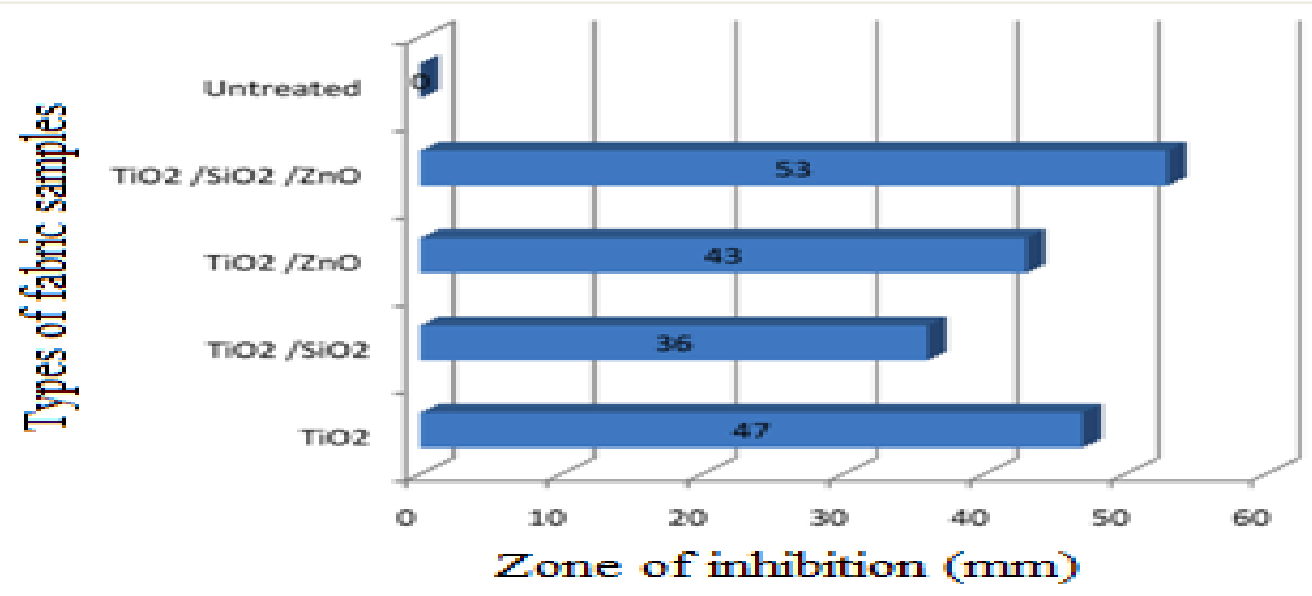

Fig.-4: Zone of inhibition
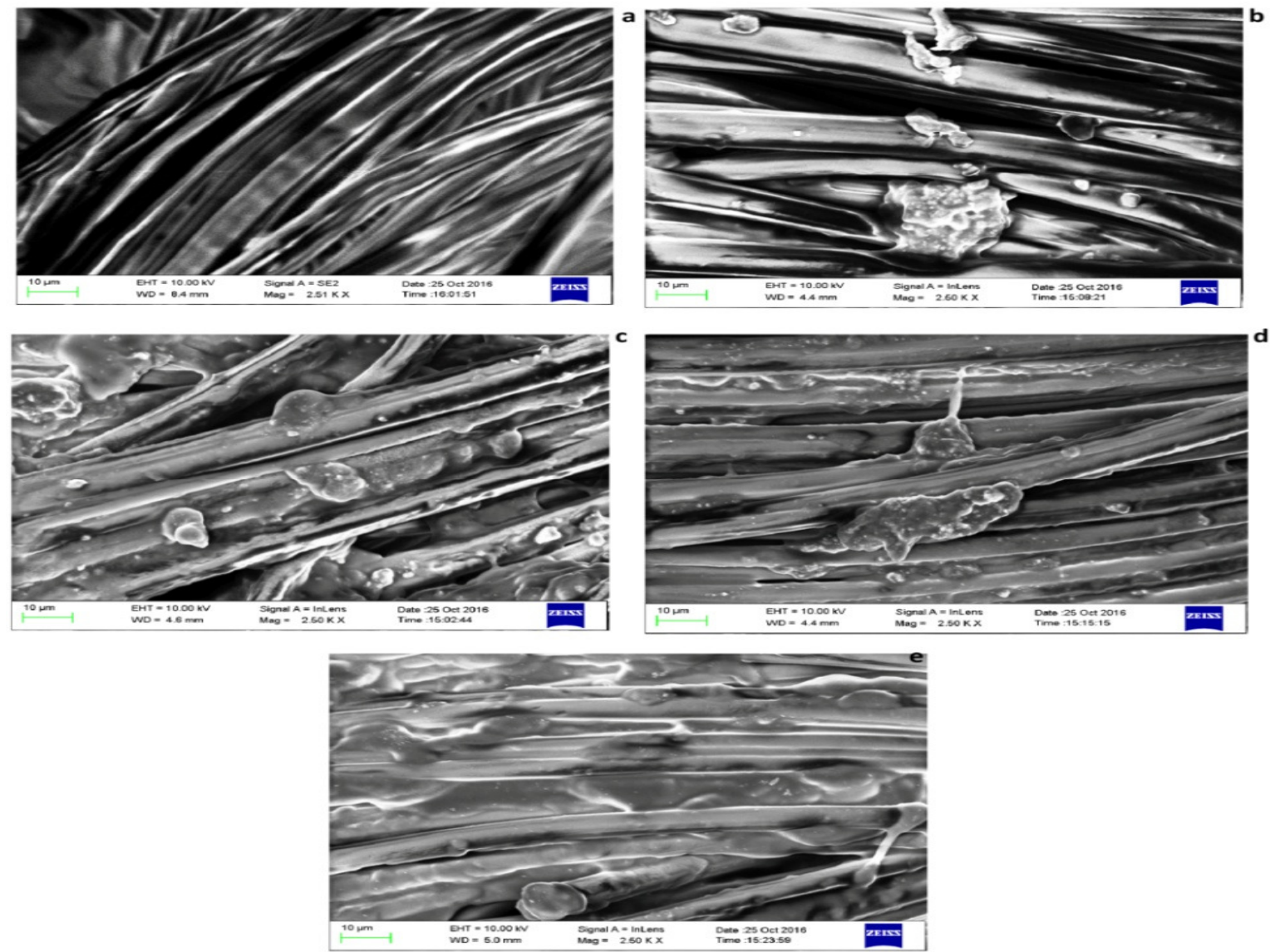

Fig.-5: Scanning electron microscope (SEM) images of (a) untreated fabric (b) Treated with $\mathrm{TiO}_{2}$ (c) treated with $\mathrm{TiO}_{2} / \mathrm{SiO}_{2}(\mathrm{~d})$ treated With $\mathrm{TiO}_{2} / \mathrm{ZnO}$ (e) treated with $\mathrm{TiO}_{2} / \mathrm{SiO}_{2} / \mathrm{ZnO}$ nanocomposite

It is evident from the Fig.-5(b) to 5(e) that there are presences of nanoparticles on the modal fabric. The nanoparticles are well dispersed on the fiber surfaces and are finely embedded. An uneven and agglomerated patchy coating is found in the Fig.-5(b), 5(c) and 5(d). It is clearly observed in Fig.-5(e) that the $\mathrm{TiO}_{2} / \mathrm{SiO}_{2} / \mathrm{ZnO}$ nanocomposite particles were uniformly distributed over the fiber surface when 
compared to Fig.-5(b), 5(c) and 5(d). This may be the reason for the enhanced antimicrobial efficacy when compared to other samples.

\section{CONCLUSION}

$\mathrm{TiO}_{2}$ nanoparticles, $\mathrm{TiO}_{2} / \mathrm{SiO}_{2}, \mathrm{TiO}_{2} / \mathrm{ZnO}$ and $\mathrm{TiO}_{2} / \mathrm{SiO}_{2} / \mathrm{ZnO}$ nanocomposites were prepared by the solgel method. These composites were applied to the modal fabric using dip coating method. The untreated and treated modal fabrics were characterized by SEM and FTIR. The antibacterial efficacy of treated fabrics was evaluated against Bacillus subttilis by measuring the zone of inhibition. It was observed from the study that the $\mathrm{TiO}_{2} / \mathrm{SiO}_{2} / \mathrm{ZnO}$ treated fabric has given a maximum zone of inhibition of $53 \mathrm{~mm}$. The $\mathrm{TiO}_{2}$ treated fabric has shown a zone of inhibition of $47 \mathrm{~mm}$ followed by $43 \mathrm{~mm}$ and $36 \mathrm{~mm}$ for $\mathrm{TiO}_{2} / \mathrm{ZnO}$ and $\mathrm{TiO}_{2} / \mathrm{SiO}_{2}$ untreated and treated fabrics respectively.

\section{REFERENCES}

1. C. K. Bower, J. E. Parker, A. Z. Higgins, Colloid Surface B, 25, 81, (2002).

2. Z. C. Yang, B. C. Wang, X. S. Yang, Colloid Surface, B, 41, 79, (2005).

3. B.E. Li Band Logan, Colloid Surface B, 36, 81, (2004).

4. R. Dastjerdi, M. Montazer, S. Shahsavan, Colloid Surface A, 345, 202(2009).

5. R. Dastjerdi, M.R.M. Mojtahedi, A.M. Shoshtari, J. Text. I, 101, 204, (2010).

6. X. Ren, L. Kou, H.B. Kocer, Colloid Surface A, 317, 711, (2008).

7. R. Dastjerdi, M.A. Montazer, Colloid Surface B, 79, 5, (2010).

8. L. Wang, Y. Ding, Y. Shen, J. Ind. Text., 6, 351, (2013).

9. K. Sundaresan, A. Sivakumar, C. Vigneswaran, J. Ind. Text, 41, 259, (2011).

10. J. E. Mogensen, P.E. Jørgensen, T.R. Thomsen, J. Ind. Text, 46, 361, (2015).

11. R. Rajendra, C. Balakumar, H.A.M. Ahammed, Int. J. Eng. Sci. Tech., 2, 202, (2010).

12. A. Meftahi, F. Yadegari, S. Alibakhshi, Procedia Mater. Sci., 11, 600, (2015).

13. Y. Han Sand Yang, Dyes Pigms., 64, 157, (2005).

14. H.Y. Ki, J. H. Kim, S. C. Kwon, J. Mater. Sci., 42, 8020, (2007).

15. E. Pakdel, W.A.Daoud, X. Wang, Appl. Surf. Sci., 275, 397, (2013).

16. A. A. E. H. El-Ebissy, M.N. Michael, S.K.E. Abdelhameed, J. Ind. Text., 46, 130, (2016).

17. A. Meftahi, F. Yadegari, S. Alibakhshi, Procedia Mater. Sci., 11, 600, (2015).

18. J. M. Llaudet, Lenzinger Berichte, 70, 24, (1990).

19. R. Venckatesh, K. Balachandran, Rajeswari Sivaraj, Intl. Nano Letters, 2, 15, (2012).

20. F. Carrillo, X. Colom, J.J. Sunol, Eur. Polym. J., 40, 2229, (2004).

21. X. Colom, F. Carrillo, Eur.Polym. J., 38, 2225, (2002).

22. D. A. Kumar, J.M. Shyla, F.P. Xavier, Appl. Nanosci., 2, 429 (2012).

23. A. Becheri, M. Dürr, P.L. Nostro, J Nanopart. Res., 10, 679, (2008).

24. B. Kaleji, M. Mousaei, H. Halakouie, J. Nanostruct., 5, 219, (2015).

[RJC-1927/2017] 